namentals and Landscape Plants Expt. Ctr. Saitama Pref. Annu. Rpt. p. 49-51.

Takeuchi, Y., M. Konnai, and T. Takematsu. 1987.

Bioassay methods of growth retardants (in Jap- anese). Reg. of Plants 22:130-141.

Wilfret, G.J. 1981. Height retardation of poinsettia with ICI-PP-333. HortScience 16:443. (Abstr.)
Wilkinson, R.I. and D. Richards. 1988. Influence of paclobutrazol on the growth and flowering of Camellia $\times$ Williamsii. HortScience 23:359360 .

\title{
Rooting Softwood Cuttings of Acer griseum: Promotion by Stockplant Etiolation, Inhibition by Catechol
}

\author{
Brian K. Maynard and Nina L. Bassuk \\ Department of Floriculture and Ornamental Horticulture, Cornell \\ University, Ithaca, IVY 14853
}

Additional index words. adventitious root formation, auxin, banding, light, paperbark maple, phenolics, propagation

\begin{abstract}
Effects of stockplant etiolation, stem banding, exogenous auxin, and catechol on the rooting response of softwood cuttings of paperbark maple (Acer griseum Pax.) were studied. Etiolated cuttings rooted better than light-grown cuttings, while stem banding did not affect rooting percentage (light-grown, 10\%; light-grown + banding, $18 \%$; etiolated, $41 \%$; etiolated + banding, 37\%). IBA did not promote, but catechol inhibited rooting (control, 31\%; IBA, 37\%; catechol, 17\%; IBA + catechol, $21 \%$ ). Root number was increased by IBA and unaffected by catechol. The distance from the cutting base to the first emerged root was measured as an indication of auxin toxicity. IBA interacted with etiolation and stem banding to increase this distance, which was greater in catechol-treated cuttings. Chemical names used: 1,2-benzenedio1 (catechol); 1H-indole-3-butanoic acid (IBA).
\end{abstract}

Paperbark maple is a desirable ornamental trees species that has presented a challenge to plant propagators for many years. Seed germination is normally poor (Fordham, 1969), grafting success is limited, and cuttings are generally considered difficult to root (Dirr and Heuser, 1987). However, several studies have reported some success with softwood cutting propagation of seedling material (Dirr and Heuser, 1987, p. 83). Of special interest is a study by Ming and Meyer (1983) in which cuttings from 2-year-old seedlings were soaked for $24 \mathrm{hr}$ in $1 \mathrm{H}$-indole-3 acetic acid (IAA) and the phenolic compound catechol. Up to $100 \%$ rooting was obtained after a 24-hr pre-sticking soak in a $2 \%$ aqueous ethanol $(\mathrm{EtOH})$ solution of 1.1 $\times 10^{-3} \mathrm{M}$ IAA plus $4.5 \times 10^{-3} \mathrm{M}$ catechol (193 and $495 \mathrm{mg} \cdot$ liter $^{-1}$, respectively). Their study suggested that catechol might have acted as rooting cofactor which, in conjunction with exogenous IAA, promoted rooting of several difficult-to-root maple species.

Stockplant etiolation and stem banding with Velcro have been used to stimulate rooting of softwood cuttings from both young (1year-old seedling) and mature (30-year-old specimen) stockplants of Acer griseum (Maynard and Bassuk, 1987). Though im-

Received for publication 27 Feb. 1989. The cost of publishing this paper was defrayed in part by the payment of page charges. Under postal regulations, this paper therefore must be hereby marked advertisement solely to indicate this fact. provements in rooting response were demonstrated, the best rooting percentages observed were markedly lower than those of Kling and Meyer (34\% vs. $100 \%$ ).

The objective of the present study was to investigate a combination of the methods used in the studies described above, specifically, the influences of etiolation and exogenously applied auxin and catechol on adventitious root formation in cuttings. The study was designed as a $2 \times \mathbf{2} \times \mathbf{2} \times 2$ factorial to test the effects of stockplant etiolation, Velcro-banding with IBA, and auxin or catechol soaks on the rooting of softwood basal stem cuttings of $A$. griseum. This study was undertaken to incorporate certain aspects of the work of Kling and Meyer (1983), not to replicate their study. Based on the assumption that IAA is more readily degraded than IBA in the course of a 24-hr soak (Dirr and Heuser, 1987, p. 37), we chose to substitute IBA for IAA.

Twenty 5-year-old field-grown seedling stockplants of A. griseum (Schichtel's Nursery, Orchard Park, N. Y.; provenance unknown) were potted into 2-liter plastic containers in a medium of 1 sandy loam soil: 1 sphagnum peatmoss: 1 perlite (by volume) and placed in cold storage at 5C for 8 weeks. On 1 Dec. 1987, all plants were placed in a greenhouse maintained at an average day/ night temperature of $20 \mathrm{C}$. Incandescent lamps $(100 \mathrm{~W})$, suspended $\approx 3 \mathrm{~m}$ above the stockplants and spaced $1 \mathrm{~m}$ apart, were used from 4:00 PM to 12:00 PM to extend the natural photoperiod to $\approx 16 \mathrm{hr}$ (irradiance not deter- mined). Stockplants were fertilized weekly with $200 \mathrm{mg} 20 \mathrm{~N}-10 \mathrm{P}-20 \mathrm{~K} / \mathrm{liter}$. Ten of the stockplants were forced under black cloth (>98\% shade) to produce typical etiolated growth (lack of color, lengthened internodes, succulence). Remaining stockplants were grown without shade. Two weeks later, shoots from one-half of the light-grown and etiolated plants were basally banded using 2.5-cm wide strips of Velcro coated with $0.8 \%$ IBA in talc, the standard procedure for stem banding developed by Maynard and Bassuk (1987). Etiolated plants were then acclimated to full sunlight over 4 days by first removing the cover on the north side, and then gradually rolling the cloth back each day until all 10 plants were in full sun. Basal shoot cuttings were taken 4 weeks later from positions throughout the stockplant crown and cut to a length of 7 to $10 \mathrm{~cm}$ with one pair of leaves. The terminal growth was removed. Banded shoots were cut immediately proximal to the Velcro bands and the bands removed. Four types of softwood cuttings were taken: 1) light-grown, nonbanded shoots (controls); 2) light-grown, banded shoots (banded); 3) etiolated shoots that had greened for 4 weeks (etiolated); and 4) etiolated and banded shoots, which yielded a cutting with an etiolated base (etiolated and banded).

All the cuttings were wounded along one side $(=2 \mathrm{~cm})$ by scraping to remove the bark, and the basal $1 \mathrm{~cm}$ of each cutting was soaked for $24 \mathrm{hr}$ at room temperature in one of four solutions containing 2\% ethanol: $2 \%$ ethanol only (control); $4.9 \times 10^{-4} \mathrm{M}$ IBA $(100$ $\mathrm{mg} \cdot$ liter $\left.^{-1}\right) ; 9.1 \times 10^{-4} \mathrm{M}$ catechol (100 $\mathrm{mg} \cdot$ liter $\left.^{-1}\right)$; or $4.9 \times 10-^{4} \mathrm{M} \mathrm{IBA}$ and 9.1 $\times 10-{ }^{4} \mathrm{M}$ catechol. Cuttings of each treatment were then distributed randomly into five groups of six cuttings each before insertion to a depth of $\approx 1 \mathrm{~cm}$ in a medium of 2 perlite :1 sphagnum peatmoss (v/v) in a completely randomized design. Rooting took place under mist (6 sec every 4 min from 6:00 AM to $8: 30 \mathrm{PM})$, with bottom heat $(25 \mathrm{C})$, and a 16-hr photoperiod (see above) provided by $100 \mathrm{~W}$ incandescent lamps suspended $1 \mathrm{~m}$ above the medium and spaced $1 \mathrm{~m}$ apart. Cuttings were evaluated for rooting after 38 days. Cuttings were considered rooted if they possessed one or more roots $>1 \mathrm{~mm}$ long. Rooting percentage, the number of roots per rooted cutting, and the distance from the cutting base to the first emerged root were recorded. Data were analyzed using the PROC GLM option of SAS (SAS Institute, 1985); percentage data were transformed to arcsin square root before analysis (Snedecor and Cochran, 1980).

An analysis of variance (Table 1) shows main effects and interactions among treatments. All third- and fourth-order interactions were nonsignificant and were pooled in 
Table 1. Analysis of variance of a $2 \times 2 \times 2 \times 2$ factorial examining the effect of etiolation, stem banding, exogenous auxin, and catechol on the rooting of softwood cuttings of Acer griseum. Char. acteristics evaluated after 38 days included rooting percentage, number of roots per rooted cutting, and distance from cutting base to first emerged root. The analysis is based on a completely randomized design of five replicates of six cuttings per treatment. Rooting percentages were transformed to their $\arcsin ^{1 / 2}$ equivalents before analysis (Snedecor and Cochran, 1980).

\begin{tabular}{|c|c|c|c|c|}
\hline \multirow[b]{2}{*}{ Source } & \multicolumn{4}{|c|}{ Partial sums of squares } \\
\hline & $\mathrm{df}$ & $\begin{array}{c}\text { Arcsin } \\
\text { rooting } \\
\text { percentage }\end{array}$ & $\begin{array}{l}\text { Roots per } \\
\text { rooted } \\
\text { cutting }\end{array}$ & $\begin{array}{c}\text { Distance to } \\
\text { first emerged } \\
\text { root }\end{array}$ \\
\hline Stockplant treatment & 3 & $5436.7 * * *$ & $762.2^{*}$ & $673.1^{* *}$ \\
\hline Etiolation (ET) & 1 & $5125.5 * * *$ & 18.9 & 20.9 \\
\hline Banding (BAND) & 1 & 31.2 & $734.7 * *$ & $487.8 * *$ \\
\hline $\mathrm{ET} \times \mathrm{BAND}$ & 1 & 290.0 & 46.1 & 35.4 \\
\hline Cutting soak & 3 & $2023.7 *$ & $2082.0 * * *$ & $1884.0 * * *$ \\
\hline IBA & 1 & 184.7 & $1983.3 * * *$ & $2255.4 * * *$ \\
\hline Catechol (CAT) & 1 & $1847.6^{*}$ & 1.2 & $281.2 *$ \\
\hline $\mathrm{IBA} \times \mathrm{CAT}$ & 1 & 2.2 & 44.5 & 138.8 \\
\hline Interactions & 9 & 1050.3 & 751.3 & $1512.3 *$ \\
\hline $\mathrm{ET} \times \mathrm{IBA}$ & 1 & 2.2 & 4.8 & $302.1^{*}$ \\
\hline $\mathrm{ET} \times \mathrm{CAT}$ & 1 & 4.0 & 15.6 & 86.1 \\
\hline $\mathrm{BAND} \times \mathrm{IBA}$ & 1 & 105.9 & $584.0 * *$ & $659.4 * *$ \\
\hline $\mathrm{BAND} \times \mathrm{CAT}$ & 1 & 51.6 & 51.1 & 36.2 \\
\hline Error mean square & 63 & 188.5 & 67.2 & 68.4 \\
\hline
\end{tabular}

***,**,*Significant at PR $>\mathrm{F}<0.001,0.01$, or 0.05 , respectively.

the residual error. The percentage of cuttings that formed roots was increased by stockplant etiolation (14\%, light-grown; 39\%, etiolated) and decreased by a cutting presoak in catechol $(34 \%$, not soaked in catechol; $10 \%$, soaked). Etiolated cuttings soaked in $2 \% \mathrm{EtOH}$ (control) rooted the best $(54 \%)$, while light-grown cuttings treated with catechol rooted poorly (4\%). The IBA presoak and Velcro-banding treatments did not affect rooting percentage. No treatment interactions affecting rooting percentages were apparent.

In contrast to their effects on rooting percentage, etiolation and catechol had no effect on the number of roots produced per rooted cutting (Table 1). The IBA soak before sticking increased the mean number of roots produced to 9.1 , while, in combination with Velcro-banding, the number of roots increased to 19.4. Velcro-banding alone increased the mean number of roots to only 3.1, while nontreated cuttings produced 2.7 roots.

In assessing rooting, we observed that roots frequently emerged above a rootless

Table 2. Effects of etiolation and banding stockplant treatments and an IBA cutting soak (4.9 $\left.\times 10^{-4} \mathrm{M}\right)$ on the distance $(\mathrm{mm})$ from the cutting base to the first emerged adventitious root on softwood cuttings of Acer griseum at 38 days.

\begin{tabular}{lcccr}
\hline \hline & \multicolumn{3}{c}{ Distance $(\mathrm{mm})$ base to first root } \\
\cline { 2 - 5 } & \multicolumn{2}{c}{ Etiolation ${ }^{2}$} & \multicolumn{2}{c}{ Stem banding } \\
\cline { 2 - 5 } IB A & soak $^{\mathrm{x}}$ Without & With & Without & With \\
\hline Without & 4.4 & 3.1 & 3.0 & 3.8 \\
With & 9.9 & 18.4 & 22.0 & 10.4
\end{tabular}

${ }^{2}$ Etiolation achieved by forcing shoots in darkness for 2 weeks, followed by gradual acclimation to full sunlight.

${ }^{y}$ Stem banding applied using Velcro strips $2.5 \mathrm{~cm}$ wide coated with IBA $(0.8 \%$ in talc) placed on the stem at the site of the cutting base for 1 month. ${ }^{x}$ Cuttings bases soaked to a depth of $1 \mathrm{~cm}$ for 24 $\mathrm{hr}$ at room temperature. zone of either living or necrotic tissues, This phenomenon suggested a toxicity Syndrome that has been reported by researchers using high levels of auxin in the propagation of cuttings (Chong, 1981; Dirr and Heuser, 1987). Therefore, the distance from the cutting base to the first emerged root was measured as an indicator of the degree of rooting inhibition caused by treatments to the cutting base. The distance from the cutting base to the first emerged root was generally greater in IBA-treated cuttings (Table 2). This distance was less in IBA-treated cuttings prepared from banded shoots, while stockplant etiolation interacted with the IBA soak to increase the distance from the cutting base to the first emerged root. Soaking the cuttings in catechol, independent of other treatments, increased this distance $(8.7 \mathrm{~mm}$ without catechol; $13 \mathrm{~mm}$ with).

Rooting percentages preserved in this study were much lower than those of Kling and Meyer (1983). Considering equivalent treatments, light-grown, nonbanded shoots soaked in IBA plus catechol, in this work, yielded $11 \%$ rooting, as opposed to $60 \%$ rooting in the previous study. Reasons for this difference might include the stockplant age (5- vs. 2-year-old seedlings), the type of auxin used (IBA vs. IAA), or differences in cultural conditions. We used the intermediate level of the auxin/catechol factorial examined in the study by Kling and Meyer (1983) in anticipation of observing an etiolation/banding response. Indeed, a significant improvement in rooting was observed when shoots were grown initially in darkness. However, in contrast to previous etiolation work with $A$. griseum (Maynard and Bassuk, 1987), etiolation and banding did not interact to increase rooting percentage, perhaps because of the generally improved rooting of etiolated cuttings in the present study. Comparing equivalent treatments, the highest rooting response achieved in the present study was $50 \%$ (etiolsited or etiolated and banded cuttings soaked in IBA before sticking), as opposed to $34 \%$ in our previous report for cuttings that had been etiolated and Velcro-banded with IBA on the band. In the present study, catechol reduced rooting, in contrast to the finding of Kling and Meyer (1983). However, lack of an auxin effect on rooting in our study was consistent with the observations of Kling and Meyer (1983), who observed nonsignificant increases of $0 \%$ to $20 \%$ with IAA treatment.

The number of roots produced per rooted cutting did not appear to respond catechol or IAA in the study by Kling and Meyer (1983), but we found an IBA response that yielded, on average, between 9.1 (without banding) and 19.4 (with banding) roots per cutting, The interaction of IBA and banding might represent a response to the total amount of IBA applied to the cutting base, as the combination of Velcro-banding with IBA and an IBA soak corresponds to two exposures of the cutting base to auxin before sticking. A significant response of root number to Velcro-banding was seen only in IBA-treated cuttings.

Though IBA generally increased the distance from the cutting base to the first emerged root, the IBA response was complicated by interactions occurring between IBA and both etiolation and banding. Banded cuttings soaked in IBA produced roots nearer the cutting base than did nonbanded cuttings. This result is in contrast to what might be anticipated regarding the effectof auxin concentration on rooting, as there was apparently no effect of exposing the cutting to IBA twice (i.e., IBA on a band and an IBA soak) on the distance of meting from the base, Perhaps some other aspect of the banding treatment, such as wounding or the more complete exclusion of light, promoted rooting closer to the cutting base, despite the presence of a higher auxin level, Etiolated cuttings soaked in IBA rooted farther from the cutting base, suggesting that, initally, etiolated stem tissues might have been more sensitive to IBA, e.g., exogenous IBA might supplement an already greater endogenous titer of IAA in etiolated stem tissues. Catechol also increased the distance from the cutting base at which rooting occurred, independent of other treatments, suggesting an inhibition of rooting unrelated to exogenous auxin application.

In conclusion, stockplant etiolation improved the rooting percentage of softwood basal stem cuttings from 5-year-old plants of Acer griseum. Stem banding alone had little effect on rooting percentage or the number of roots formed, while stern banding interacted with the application of hormone at sticking to increase the number of roots produced per cutting, suggesting an effect of the number of hormone applications on root initiation. IBA applied as a pre-cutting soak had no effect on rooting percentage, but increased the number of roots formed per gutting and the distance from the cutting base at which rooting occurred. Catechol acted to reduce rooting potential by reducing the per- 
centage of cuttings that rooted and by inhibiting the development of roots near the cutting base. No interactions were observed between stockplant etiolation or banding of stems and exogenously applied catechol.

\section{Literature Cited}

Chong, C. 1981. Influence of high IBA concentrations on rooting. Proc. Intl. Plant Prop. Soc. $31: 453-460$.
Dirr, M.A. and C.W. Heuser, Jr. 1987. The reference manual of woody plant propagation: From seed to tissue culture. Varsity, Athens, Ga.

Fordham, A.F. 1969. Acer griseum and its propagation. Proc. Intl. Plant Prop. Soc. 19:346348.

Kling, G.J. and M.M. Meyer, Jr. 1983. Effects of phenolic compounds and indoleacetic acid on adventitious root initiation in cuttings of Phaseolus aureus, Acer saccharinum, and Acer gri- seum. HortScience 18(3):352-354.

Maynard, B.K. and N.L. Bassuk. 1987. Stockplant etiolation and blanching of woody plants prior to cutting propagation. J. Amer. Soc. Hort. Sci. 112(2):273-276.

SAS Institute, Inc. 1985. SAS user's guide: Statistics. 5th ed. SAS Institute Inc., Cary, N.C.

Snedecor, G.W. and W.G. Cochran. 1980. Statistical methods. 7th ed. Iowa State Univ. Press, Ames.

\section{Growth of Four Tropical Foliage Species Treated with Paclobutrazol or Uniconazole}

\author{
Yin-Tung Wang and Thomas M. Blessington ${ }^{2}$ \\ Texas A\&M University Agricultural Research and Extension Center, \\ 2415 East Highway 83, Weslaco, TX 78596
}

Additional index words. growth retardant, height control, Brassaia actinophylla, Codiaeum variegatum, Syngonium podophyllum, Plectranthus australis, PP333, XE-1019, sumagic, bonzi

\begin{abstract}
Uniconazole and paclobutrazol were tested for their effects on greenhouse production of four foliage species. Soil drenches of uniconazole retarded shoot and petiole elongation of Brassaia actinophylla Endl. Paclobutrazol reduced shoot elongation, but required higher doses than uniconazole and did not reduce petiole growth. Foliar sprays with either retardant at $12.5 \mathrm{mg} \cdot \mathrm{liter}^{-1}$ resulted in short stems on lateral shoots of Codiaeum variegatum (L.) Blume 'Karen' after pinching, but soil drenches at low rates were less effective. Soil drenches of uniconazole or paclobutrazol were equally effective in reducing stem growth of Syngonium podophyllum Schott 'White Butterfly' and increasing leaf width, but had no effect on the rate of leaf production or blade length. Both retardants induced short petioles in this species. Severe growth reduction occured on Plectranthus australis R. Br. even at the lowest rates of uniconazole and paclobutrazol $(0.025$ and $0.20 \mathrm{mg} /$ pot, respectively) as soil drenches. Production of lateral shoots was inhibited for $\boldsymbol{P}$. australis by both retardants. Chemical names used: (E)-1-(p-chlorophenyl) -4,4 -dimethy1-2-(1,2,4 -triazol-1-yl)-1-penten-3-ol (uniconazole); (2RS,3RS)-1-(4-chlorophenyl)-2-(1,1-dimethylethyl)-(H-1,2,4-triazol-l-Yl-)Dentan-3-ol (paclobutrazol).
\end{abstract}

Research to determine the effect of uniconazole and paclobutrazol on tropical foliage plants has been limited. Uniconazole retarded plant growth and promoted secondary branching in Peperomia obtusifolia, but reduced leaf size (Mansour and Poole, 1987). Plant growth, rate of leaf production, and leaf size of Ficus benjamina were reduced by drenching the medium with paclobutrazol (LeCain et al., 1986). Since foliage plants are often produced under heavy shade and in close proximity, controlling plant height by means of retardant application would make plants sturdier and more attractive. Brassaia

Received for publication 30 Jan. 1989. This research was supported in part by a grant from Valent U.S.A. Corp., Richmond, Calif. The cost of publishing this paper was defrayed in part by the payment of page charges. Under postal regulations, this paper therefore must be hereby marked advertisement solely to indicate this fact.

'Assistant Professor.

'Professor and Center Director. actinophylla has long internodes and petioles when produced under shade. Codiaeum variegatum 'Karen', after pinching, produces lateral shoots with long stems under the lowest leaf, making plants unattractive. Syngonium podophyllum and Plectranthus australis have long internodes, making plants less compact. The objective of this study was to determine the effect of paclobutrazol and uniconazole on growth characteristics of the above four tropical foliage species during summer production.

Two-liter pots filled with Sunshine Mix No. 1 (a peat-lite mix without bark; Fisons, Vancouver, B. C., Canada) were used in all experiments. Plants were grown in shadehouses covered with polypropylene shade fabric and a layer of polyethylene $(0.15 \mathrm{~mm}$ thick), providing a maximum photosynthetic photon flux of $420 \mu \mathrm{mol} \cdot \mathrm{s}^{-1} \cdot \mathrm{m}^{-2}$. Plants were irrigated with water containing a $24 \mathrm{~N}-3.4 \mathrm{P}-$ $13.3 \mathrm{~K}$ water soluble fertilizer at $0.83 \mathrm{~g} \cdot$ liter $^{-1}$ (W.R. Grace, Fogelsville, Pa.) when medium surface became light in color. Air tem- peratures ranged between 15 and 39C. Growth retardant drench and spray solutions contained $0.1 \%$ Tween 20. Soil drenches were applied as 150-ml solutions.

Seedlings of B. actinophylla averaging 15 $\mathrm{cm}$ tall were planted one per pot on 1 Mar. 1988. Plants received soil drenches of uniconazole (XE-1019, Sumagic, Valent U. S. A., Richmond, Calif.) at 0, 0.025, 0.050, 0.10, $0.20,0.40,0.80$ or $1.00 \mathrm{mg} /$ pot or paclobutrazol (PP-333, Bonzi, Sandoz Crop Protection, Chicago) at 0, 0.20,0.40,0.60,0.80, 1.00 , or $1.20 \mathrm{mg} /$ pot on $26 \mathrm{Apr}$. 1988. The youngest fully expanded leaf on each plant was tagged at treatment. Plants were evaluated on 18 July 1988 for number of new leaves, stem growth (measured from the tagged node to stem apex), overall plant height (measured from pot rim to the tallest point), and petiole length of the three most acropetal fully expanded leaves. Each plant was an experimental unit, and treatments were replicated 10 times using a randomized complete-block design (RCBD).

Shoot tip cuttings of $C$. variegatum 'Karen' with stems averaging $10 \mathrm{~cm}$ long were taken on 26 Feb. 1988 and rooted one per pot in 2-liter pots under intermittent mist for 60 days. Rooted cuttings were grown under the same conditions as given for $B$. actinophylla. Spray applications of uniconazole or paclobutrazol at $0,12.5,25,50$, or $75 \mathrm{mg} \cdot$ liter $^{-1}$ were made on 8 June 1988, immediately after cutting the shoots to $10 \mathrm{~cm}$. Plants were sprayed to run-off with an average of $20 \mathrm{ml} / \mathrm{plant}$, while the medium surface was covered with polyethylene to prevent the solution from getting into pots. Another group of plants received soil drenches containing uniconazole or paclobutrazol at $0,0.50,0.10,0.20$, or $0.40 \mathrm{mg} / \mathrm{plant}$. Each retardant and method of application was a separate experiment. Plants were arranged in a RCBD with a single plant per pot as an experimental unit, and treatments were replicated six times. Plants were evaluated on 15 July 1988 for number of lateral shoots and for the length of the first internode on the two uppermost shoots.

S. podophyllum 'White Butterfly' were planted one per pot on 3 Feb. 1988. Each plant received a soil drench of uniconazole $(0,0.025,0.05,0.10,0.20,0.40,0.60$, or $0.80 \mathrm{mg} / \mathrm{pot})$ or paclobutrazol $(0,0.20,0.40$, $0.60,0.80$, or $1.00 \mathrm{mg} / \mathrm{pot}$ ) on $27 \mathrm{Apr}$. 1988 . The uppermost leaf on each plant was labeled before treatment. Plants were arranged in a RCBD with eight replications per treat- 